\title{
WHICH RELATIONSHIP BETWEEN GREEK GODS AND ROMAN EMPERORS? THE CULTIC IMPLICATIONS OF THE “ASSIMILATION" OF EMPERORS TO GODS IN MAINLAND GREECE* \\ ¿CUÁL ERA LA RELACIÓN ENTRE DIOSES GRIEGOS \\ Y EMPERADORES ROMANOS? IMPLICACIONES CULTUALES \\ DE LA “ASIMILACIÓN” DE EMPERADORES \\ A DIOSES EN LA GRECIA CONTINENTAL
}

\author{
Francesco Camia \\ SAPIENZA UNIVERSITÀ DI ROMA \\ FRANCESCO.CAMIA@UNIROMA1.IT
}

\begin{abstract}
In the Greek world Roman emperors were often linked with traditional gods. Verbal and iconographical assimilations on inscriptions, coins and statues, integration into pre-existing sacred structures and festivals, and joint priesthoods were three different means of establishing a relationship between the old gods of the Greek pantheon and the new divinized masters of the Empire. The ideological valency of this proceeding was strong, as it permitted the
\end{abstract}

\begin{abstract}
RESUMEN
En el mundo griego, a los emperadores romanos se les relacionaban con los dioses tradicionales. Las asimilaciones verbales e iconográficas en inscripciones, monedas y estatuas, la integración en estructuras y festivales sagrados preexistentes y los sacerdocios conjuntos eran tres medidas diferentes para establecer una relación entre los dioses antiguos del panteón griego y los nuevos gobernantes divinizados del Imperio. El aspecto ideológico de este procedimiento era
\end{abstract}

\footnotetext{
* This article has been researched within the project Adriano y la integración de la diversidad regional. Una perspectiva histórica e historiográfica (HAR2015-65451-C2-1-P), 01/01/2016 - 31/12/2018 of the University Pablo de Olavide. I warmly thank the editors of this volume for inviting me to contribute to it and the two anonymous reviewers for their useful comments, which greatly improved the final result and saved me from inaccuracies and imperfections. Thanks are also due to Paul Beston for revising the English text.
} 
Greek elites both to establish a subtle hierarchy between emperors and gods and to cope with the new imperial power through traditional tools (and according to Greeks' cultural horizon). As is generally the case with the "imperial cult" as a whole, however, the assimilation of emperors to the traditional Greek gods had also significant cultic implications, since ritual ceremonies were performed for the emperors. In this context priests of the imperial cult played an important role. The present paper deals with these aspects in the cities of mainland Greece. fuerte, ya que permitió a las élites griegas establecer una jerarquía sutil entre emperadores y dioses, y gestionar al nuevo poder imperial a través de herramientas tradicionales (según el horizonte cultural de los griegos). Sin embargo, como en general es el caso del "culto imperial" en su conjunto, la asimilación de los emperadores a los dioses griegos tradicionales también tenía importantes implicaciones cultuales, ya que las ceremonias rituales eran celebradas para los emperadores. En este contexto los sacerdotes del culto imperial jugaban un papel importante. El presente capítulo trata sobre estos aspectos en las ciudades de la Grecia continental.

\section{KEYWORDS}

Imperial cult, priests, ritual practices, Roman Greece

\section{Palabras Clave}

Culto imperial, sacerdotes, prácticas rituales, Grecia romana 


\section{ROMAN EMPERORS AND GREEK GODS: A MULTIFACETED ASSOCiATiON (AND ITS “PITFALls")}

More than thirty years after Simon Price's seminal study on the imperial cult in Asia Minor, it can be said that the religious character of emperor worship has been acknowledged in the scholarly debate. Some of the very features of Greco-Roman religion, such as polytheism, the plurality of conceptions of the divine, and the close interconnection between on the one hand human and divine spheres, on the other politics and religion, made possible that mortals provided with autocratic power were worshipped like gods, being paid proper cults served by dedicated priests in a specific place. ${ }^{1}$ Yet, how were emperors treated in comparison with (and with respect to) traditional gods? The way emperors were associated in the Greek world with the gods of the civic pantheons may tell us something more about their "status" (or the way subjects of the empire, mainly the elites, perceived it).

Following Nero's proclamation of the "liberation" of Greece in $\mathrm{AD} 67,{ }^{2}$ the Boeotian polis of Akraiphia resolved, at the initiative of the benefactor Epaminondas, to (re-)consecrate to the emperor the altar located in the sanctuary of Zeus Soter in the city's agora. Nero would come to receive sacrificial offerings in the sanctuary of the god in association with Zeus Soter, whose cult at Akraiphia was naturally presided over by a priest and amplified by agones. ${ }^{3}$ In the dedication to be inscribed on the altar, however, Zeus is given the epithet Eleutherios, directly followed by the name of Nero (later martellated). ${ }^{4}$ There is no evidence that Zeus Soter was also worshipped at Akraiphia with the epithet Eleutherios, as was the case in

1. Price, 1984. Among the copious bibliography on Roman imperial cult see most recently Clauss, 1999; Gradel, 2002; Fishwick, 1987-2004; Chaniotis, 2003a; Iossif, Chankowski, and Lorber, 2011; Brodd and Reed, 2011; Kolb and Vitale, 2016.

2. IG VII 2713, 11. 1-26; Paus., VII 17, 3.

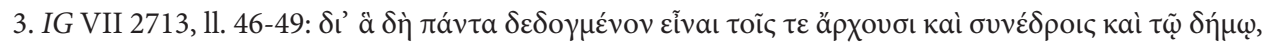

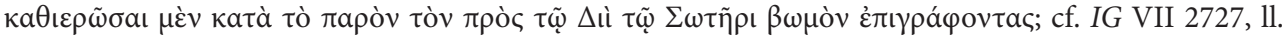
1-6 (agones and priest). For the cult of Zeus Soter at Akraiphia see Schachter, 1981-1994, 3, pp. 93-95; Manieri, 2009, pp. 78-79.

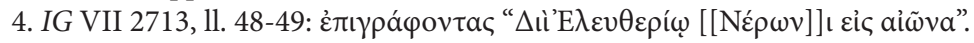


the agora of Athens, ${ }^{5}$ so the presence together of Zeus Eleutherios and Nero, which effectively assimilates the emperor to the god, was a strategic move directly related to the proclamation of the eleutheria of the Greeks in $\mathrm{AD}$ 67. In other words, the decisive factor in determining Akraiphia's choice of associating the emperor with the cult of Zeus Soter was the desire to celebrate Nero and his decision to "free" Greece by assigning him the epithet Eleutherios.

This episode shows well the complexity, not to say the ambiguity, implied in the assimilation of an emperor to a god. This practice had important precedents in the Hellenistic period. ${ }^{6}$ In Greek cities, Roman emperors were identified with traditional gods, either epigraphically by juxtaposing the name of a god or a divine epithet to the emperor's name in inscriptions (and coins), or iconographically by representing the emperor with the attributes of a given god on statues (and coins). All over Greece and the Greek East, for example, altars were dedicated to Hadrian Olympios. ${ }^{7}$ The philhellene emperor was also honoured as (neos) Pythios at Megara by its tribes and the civic bodies (boule and demos) and as neos Dionysos in Athens by the ecumenical association of the Dionysiac artists. ${ }^{8}$ This phenomenon did not

5. For Zeus Eleutherios/Soter in the Athenian agora cf. Wycherley, 1957, pp. 25-30. A famous cult of Zeus Eleutherios was that at nearby Plataea; cf. Graf, 2011, pp. 109-110.

6. This is a very large topic, which is beyond the scope of the present paper; see especially Habicht's seminal study (Habicht, 1970) and, more recently, Chaniotis, 2003b. On Thera the sanctuary of Dionysus, where at the latest by the reign of Ptolemy VI the Ptolemaic kings were worshipped, may have housed the cult of the emperors: an altar found in the area of Dioysus' sanctuary was dedicated to Augustus by the Theran demos in the very first years of the Principate (IG XII 3, 469 - the name of the emperor appears in the genitive case); from the same area also comes a honorary inscription for Augustus (IG XII 3, 470). Furthermore, the $a[$ rchaio $] n$ Kaisareion mentioned in an Antonine inscription (IG XII 3, 326, 1. 26) might be identical with the temple of Dionysus; cf. Hänlein-Schäfer, 1985, pp. 184-185, A37; Witschel, 1997, pp. 30-31 (and n. 117), 45-46. The link with Dionysus' cult, both for the Hellenistic kings (in particular the Ptolemies, who claimed descent from that god - see FGrH $631 \mathrm{~F}$ 1, with Dunand, 1986, p. 87, n. 10, and Goyette, 2010) and Roman emperors, is attested in other places as well; cf. Ohlemutz, 1940, pp. 90-122, esp. 115-117; Bru and Demirer, 2007, pp. 44-46. At Eretria in Euboia the temple that in the imperial period was transformed into a Sebasteion may have housed a cult of the

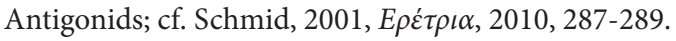

7. The most conspicuous group is represented by the over one hundred altars from Athens, to which I will refer later; see infra, n. 57.

8. Megara: IG VII 70-72, 3491; see also IG V 2, 127 (Tegea): fragmentary dedication of a balaneion and a stoa in which Hadrian is probably mentioned as Pythios in addition to Olympios and Panhellenios. Athens: SEG XLVII 222; see also SEG XLI 143: honorary inscription probably from the Acropolis by the Lydian city of Philadelphia for Hadrian, who is mentioned as theos neos Dionysos (1. 6); IG $\mathrm{II}^{2} 3323$ : perhaps an altar dedication by the technitai for Hadrian as neos Dionysos, yet see Benjamin, 1963, pp. 71-72 (SEG XXI 802) for a different interpretation (dedication to Heracles and Dionysus). 
solely relate to Hadrian, of course. Just to cite some examples from Greece, Trajan was identified with Zeus Embaterios on a honorary inscription from Peloponnesian Hermione, ${ }^{9}$ while at Sparta about 40 altars were dedicated to Antoninus Pius identified with Zeus Eleutherios. ${ }^{10}$ Furthermore, one should also consider that in the Greek world the living emperor was quite often designated as theos. There is a significant difference, however, between the mere recognition of the supra-human nature of the emperor by assigning him the epithet theos and his integration into the specific pantheon of a polis through his assimilation to (or combination with) a specific deity.

The epigraphic or iconographic assimilation of the emperor to a god does not eo ipso imply the existence of a cult of that emperor in association with the god. In 1962 Paul Veyne had well expressed this concept by stating: "non pas que l'identification à une divinité soit synonyme de divinisation et que divinisation signifie culte: de pareils syllogismes théologiques ne sont guère concluants pour l'époque". ${ }^{11}$ Indeed, in many cases these forms of divine assimilation were simply functional to the integration of the imperial power into the symbolic system of Greek cities, and they may have been prompted for largely ideological reasons by a particular episode, as was no doubt the case at Akraiphia. Ultimately, what matters is the manner in which the assimilation occurs: an altar with a dedication (in the dative or genitive) to an emperor identified with a god, or a cult statue of an emperor with the attributes of a god within the latter's temple point to the existence of some form of joint cult, probably including rituals such as sacrifices. Even in these cases, however, assimilation of an emperor with a god can be subject to ambiguity. Let us consider the Spartan altars in honour of Antoninus Pius identified with Zeus Eleutherios referred to above. While they may attest to the offering of sacrifices (or libations) to this emperor in connection with Zeus Eleutherios, we cannot be certain that at Sparta there was a regular cult of Antoninus Pius in association with Zeus, since there is neither definitive evidence in the city of a priesthood of Zeus Eleutherios, nor a known sanctuary of the god. In other words, we cannot tell if there was at that moment an "active" cult of the god to whom Antoninus was assimilated as recipient of offerings. ${ }^{12}$

9. IG IV 701; cf. Richards, 1988.

10. See infra n. 70 .

11. Veyne, 1962, p. 61.

12. The Homonoia treaty between Sparta and Synnada [IG V 1, 452 add. p. 303 (SEG XI 771)] could attest to the existence of a priest of Zeus Eleutherios, but this is not certain; cf. Hupfloher, 2000, p. 165. 
To identify an emperor with a god in inscriptions and coins or to depict him with divine attributes was by no means the only strategy for linking emperors to gods. The emperor might be incorporated into an existing sacred complex or integrated into a traditional religious festival. These different modes of integrating emperors and traditional gods raise a fundamental issue, namely how we are to identify cult practices for the emperors, which in turn involves the interpretation of the imperial cult as a whole.

When trying to recognise ritual practices for the emperors in the evidence, among the main features of cults (cult place, festival and cult ceremonies, cult personnel) the first poses the toughest problems. Terms like Sebasteion or Kaisareion of course offer a direct testimony of a cult place for the emperors; yet sanctuaries of the imperial cult have other, more "neutral", terms in the sources. Emperors could also be worshipped in other places as well - theatres, stoai, gymnasia, and so on. This is clearly shown by the case of "old" Greece (Achaia provincia): there the terms Sebasteion/Kaisareion occur in the evidence only with reference to Gytheum and Messene, ${ }^{13}$ although many other cities worshipped emperors in cult places, whether they were reserved for the imperial cult or not. In fact, in many cases emperors were worshipped in pre-existing cult places in association with traditional gods. That it is not easy to identify such cases is shown by the following examples, which consider two common practices in the cities of the Greek world in the imperial period. One relates to the dedication of secular and religious edifices to the emperor - who usually appears in the dedicatory inscription together with one or more deities, often the main god(s) of the city - and the polis or one of its civic bodies. These "multiple" dedications are by no means proof of a cult for the emperor in combination with the god mentioned next to him. In many cases they are rather to be interpreted as an expression of allegiance towards Rome: mentioning the emperor in a building's dedicatory inscription together with the main god and the polis (the latter usually indicating the public nature of the structure) is a means of paying homage to the Domus Augusta and the Roman state. ${ }^{14}$ The second practice consists of setting up imperial images in a temple or other sacred structure. As in the first case, this does not automatically imply that the cult practices for the god

13. Gytheum: SEG XI 923 (1. 28). Messene: IG V 1, 1462 (with Bardani, 1988); SEG XXIII 207 (1. 39); SEG LXIII 289 (1. 31).

14. Cf. Veyne, 1962, pp. 65-67, 81-83. The probability that the emperor actually received a cult is of course higher when his name appears alone next to the name of the god in the dedicatory inscription of a sacred structure such as a temple. 
involved the emperor as well. ${ }^{15}$ In fact, in many cases imperial images were just honorific and did not have any cultic value. The imperial eikones which Pausanias saw inside an old sanctuary (hieron) dedicated to Artemis Soteira at Megara, for example, were most likely simply honorific statues. ${ }^{16}$

More certain indicators of a worship of the emperors together with the gods can be found in connection with imperial festivals and priests. Even these elements, however, pose a few issues. The integration of the emperors into a traditional religious festival is usually revealed by a change in the festival's name through the addition of an epithet such as Kaisareia or Sebasteia. A modification in the agonistic programme can also occur, leading to the institution of new contests specifically for the emperors. Indeed, in "old" Greece emperors came to be worshipped in the context of some of the most important traditional festivals, such as the Isthmia, the Nemeia, the Epidaurian Asklepieia, the Thespian Mouseia. ${ }^{17}$ However, the addition of the epithets Kaisareia/Sebasteia to the name of a traditional festival seems sometime to have been the result of a transient modification rather than implying the worship of the emperors in association with the god to which the festival was dedicated. In particular, as noted by S. Price, it cannot be stated for certain that sacrifices were made always both to the god and the emperor. ${ }^{18}$ Indeed, every case should be analysed independently and according to the evidence available. ${ }^{19}$

15. Cf. Fujii, 2013, p. 58: "the mere presence of an image of the emperor in a sacred site does not affirm his status as theos synnaos of the deities venerated there"; see also ibidem, 50-51.

16. Paus., I 40, 2-3; in this specific case, moreover, even the agalma of the goddess may have been an ex-voto rather than an actual cult image, as stated by Muller, 1981. An ambiguous case is that of the statues of emperors set up inside one of the temples of the Marmaria sanctuary dedicated to Athena Pronaia at Delphi, probably the so-called tholos; Pausanias $(\mathrm{X} \mathrm{8,6)}$ does not provide any further detail on the nature of these imperial images, so that it remains uncertain if the temple was ever used to worship the emperors (in combination with the goddess Athena); cf. Roux, 1965; Kantirea, 2007, pp. 153-154; Camia, 2011a, pp. 226-227.

17. See e.g. IG IV 795; Corinth VIII.1, 80-81; Corinth VIII.2, 68 (Isthmia); IG IV 587, 590, 602, 606

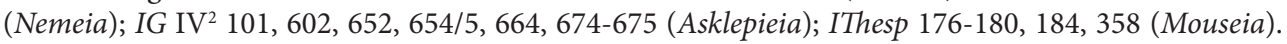
On these and other imperial festivals in Greece see Camia, 2011a, 85-131 (and 274-278). Emperors themselves could 'upgrade' an existing festival, see e.g. the Nicopolitan Megala Actia Kaisareia re-founded on Augustus' initiative (Strabo, VII 7, 6; see e.g. FD III 1, 537 and cf. Zachos, 2015, pp. 60-62).

18. Price, 1984, p. 212: "though the joint name prima facie implies equality between the old god and the emperor, it would be rash to assume that sacrifices were made to both. Practice may have varied even at one festival"

19. See e.g. IGRR IV 1273 (11. 10-11): the agonothetes of the first edition of the Sebastea Tyrimnea of Thyateira in Lydia celebrated prayers and sacrifices both to the god and the emperors; see also IGRR IV 1270 (11. 13-14). 
As for priests, one should first distinguish between individuals who assumed multiple priesthoods, even at the same time, and actual "double" priesthoods which combined the emperor and a traditional god. ${ }^{20}$

Ultimately, it is not easy to recognise in the evidence those cases in which the combination of an emperor with a specific god implied cultic celebrations, and the task may offer a few "pitfalls". This is compounded by the fact that, in general, testimonies of ritual practices such as sacrifices for the emperors are quite limited, at least in the Greek peninsula. Yet the identification of such cases is fundamental not only to a better understanding of how emperors were integrated into the local pantheons of Greek cities but also to definitely overcoming the traditional interpretation of the imperial cult as a (mainly) secular and political phenomenon.

In the following pages, largely using epigraphic evidence, I shall deal with cult practices for emperors together with traditional gods, and the role played by priests of the imperial cult. In order to do so I have adopted as a case study mainland Greece, especially its southern and central regions, i.e. that part that roughly corresponds to the Roman province of Achaia. This is also the reason why most of the evidence referred in my paper comes from this part of the Greek world. However, my reasoning usually holds true for (most of) the rest of the Greek world as well, as the cases that I (admittedly only occasionally) shall refer from other areas (namely Macedonia and Asia Minor) seem to indicate. It is worth noting that I am not going to consider the supra-civic level, limiting myself to emperor worship in single cities. ${ }^{21}$ Finally, given the specificity of this theme, I will not limit my analysis to the second century. Let us start by considering which gods were more frequently associated with Roman emperors in mainland Greece. ${ }^{22}$

\section{WHICH GODS?}

In the cities of "old" Greece emperors were linked with virtually all of the twelve Olympian gods who formed the traditional Greek pantheon codified by epic, i.e. Zeus, Hera, Poseidon, Demeter, Apollo, Artemis, Ares, Aphrodite, Hermes, Athena, Hestia (or Dionysus). ${ }^{23}$ The twelfth, Hephaestus, is to my knowledge never found

20. See infra for examples of these "double" priesthoods.

21. On the imperial cult at the supra-civic level in the Roman East with particular reference to the high priests of the emperors see most recently Vitale, 2016.

22. On the imperial cult in Greece see Kantirea, 2007; Lozano Gomez, 2010; Camia, 2011 a.

23. Dowden, 2007. Different variants of the "Twelve Gods" are attested in the Greek world; cf. Rutherford 2010, pp. 46-48. 
in connection with a Roman emperor, a fact that may find a plausible explanation in the very nature of this god: his intimate association with a natural element (fire) as well as his physical imperfection (crippled feet) made Hephaestus an 'outsider' even among the Olympian gods, and this finds a reflection in the well-known accounts of his "fall" from heaven, and in the Homeric laughter he is subjected to both in the Iliad and the Odyssey. ${ }^{24}$

In addition to the canonical Panhellenic gods, we also find emperors in association with other related deities, namely Zeus' son Asclepius with his feminine counterpart Hygeia. ${ }^{25}$ There is also evidence for a number of lesser gods, including Eros and the Muses at Thespiae, where festivals called Sebasteia Mouseia and Kaisareia Erotideia Rhomaia were celebrated; ${ }^{26}$ Tyche at Gytheum in connection with Livia and at Tanagra in connection with Flavia Domitilla; ${ }^{27}$ and the demi-god Heracles together with Hermes as deities of the gymnasium at Akraiphia in the context of a joint sacrifice to them and the Sebastoi. ${ }^{28}$

When associated with the Sebastoi as a whole or with a specific imperial figure, the different gods are generally specified by a divine epithet, such as Eleutherios, Soter, Isthmios, and so on. These epithets usually linked these gods with a specific cult located in a specific sanctuary. Just to give some examples: at Athens the emperors were worshipped together with Zeus Eleutherios in the annexe added in the early Principate to the stoa dedicated to that god in the Agora. ${ }^{29}$ As already noted, at Akraiphia an altar was dedicated to Nero (identified with Zeus Eleutherios) in the sanctuary of Zeus Soter in the agora. ${ }^{30}$ At Isthmia, from the early Principate, the emperors were associated with the trieteric festival celebrated for Poseidon Isthmios $^{31}$. The characterization of a god by means of a specific epithet, which defines

24. Burkert, 1985, pp. 167-168. Il. I, 571-600; Od. VIII, 266-366; for Hera’s episode see Burkert, 1985, p. 401, nn. 47-48.

25. IG II-III ${ }^{2}$ 3120: epistyle with dedication to Asclepius, Hygeia and Augustus; cf. Travlos, 1971, p. 128; Baldassarri, 1998, pp. 67-73; Kantirea, 2007, p. 137; Aleshire, 1989, p. 7. IG II-III ${ }^{2} 3176$ : dedication to Asclepius, Hygeia and Augustus; cf. Kantirea, 2007, p. 138.

26. See e.g. I.Thesp. 176, 180, 358, 376-377; cf. Camia, 2011a, p. 126.

27. SEG XI 923 (Gytheum), 11. 9-10. IG VII 572 (Tanagra): likely Vespasian's daughter Domitilla the Younger; cf. Kantirea, 2007, p. 87. At Troezen a hiereus of the Tyche Sebaste (= Fortuna Augusta) is attested (IG IV 799); cf. Camia, 2011a, pp. 216-217.

28. IG VII 2712, 11. 22-23.

29. Thompson, 1966.

30. See supra, n. 3.

31. IG IV 795 (1l. 8-9); Corinth VIII.1, nnº 80-81 (1. 2); VIII.2, nº 71 (1. 5); cf. Camia, 2011a, pp. 112 115. At Nicopolis Hadrian and his wife Sabina received altars as Zeus Dodonaios and Artemis Kelkaia respectively (see infra, n. 66). 
and limits its sphere of action, is one of the main features of Greek polytheism and accounts for the multitude of divine figures which formed the Greek local pantheons: as has been noted, one could even say that in the Greek world there were as many gods as sanctuaries. ${ }^{32}$ From this consideration some interesting consequences result with regard to the imperial cult. Emperors were linked with specific cults in specific sanctuaries, a fact that contributes to showing that - at least sometimes - they were worshipped like traditional gods. Moreover, in a place in which there were several sanctuaries (and cults) of the same god with different epithets, emperors may have been associated with only one of them: at Athens, for example, there is evidence for connecting the cult of the emperors to Apollo $\mathrm{Pa}$ troos (worshipped in the Agora) ${ }^{33}$ but not to other cults of Apollo (e.g. Daphnephoros, Lykeios, Zosterios). Still in Athens, it is enough to look at the gods mentioned in the inscribed seats of the theatre of Dionysus, which give an interesting, albeit partial, picture of the Athenian "active" cultic pantheon in the late Hellenistic and Imperial periods, to realise how many divine figures were not linked with the emperors. Indeed, it is worth noting more generally that many gods, often of purely local valency, whose cult continued to be celebrated during the imperial period in the cities of mainland Greece, are never found in our sources in association with Roman emperors.

Allowing for possible lacunae in the evidence, can we say something about these absences? Apart from very specific divine figures or heroes linked with the local mythological traditions, we can recognise two main categories of gods that to my knowledge are not attested in connection with emperors in the cities of "old" Greece. One is that of the deities of nature, such as Gaia/Ge, Helios, Selene, Oceanus, etc. ${ }^{34}$ The other, and more interesting, group with regard to the period in question is represented by the so-called Egyptian and Oriental gods such as Isis, Serapis, Sabazius, etc., whose cults spread throughout the Roman empire. Given their foreign nature, and notwithstanding their popularity, they may have not been considered as the most suitable synnaoi for emperors. The exotic (and unofficial)

32. E. Kearn, $O C D^{3}$, 1301; cf. Burkert, 1985, p. 170: “The gods are beyond number - no exhaustive list can be given".

33. Camia, 2011a, pp. 197-198.

34. Burkert, 1985, pp. 174-176. The relationship between the cult of Helios and the imperial cult, especially in the case of emperors such as Nero and Elagabalus, is well attested in the East; see Bru, 2016, p. 61. Hadrian is called neos Helios at Klazomenai (IGRR IV 1551). In the East the emperors were sometimes recognised specific qualities in connection with the control of natural elements; cf. Bru, 2016, p. 58.

ARYS, 16, 2018 [105-137] ISSN 1575-166X 
character of these cults, in some cases only recently admitted to the local pantheon, may have played a role in preventing a connection with the imperial cult. ${ }^{35}$ There is a surely significant contrast here with Meter Theon-Cybele, a deity with Anatolian roots, who may have been associated with the imperial cult in Greece. The Metroon in the sanctuary of Olympia was re-consecrated to the emperor Augustus. The old temple dedicated to the Mother of the Gods, which had been built between the end of the fifth and the beginning of the fourth centuries BC, had long lain in ruins by the time it was re-consecrated to Augustus alone, as shown by the dedicatory inscription on the epistyle. ${ }^{36}$ Based on Pausanias' testimony (V 14, 9), however, it can be suggested that the altar in front of the new Metroon continued to be used to sacrifice to Rhea/Meter Theon; if it were also used to sacrifice to the emperors, the latter would come to be worshipped together with the old goddess. ${ }^{37}$ Yet this would be only an apparent exception to the previous point regarding foreign gods who were not usually associated with the imperial cult in Greece, since Cybele had been early adopted by the Greeks of Asia and quite soon came to be integrated into the Hellenic pantheon, as is further confirmed by the relatively early date of the dedication of the Metroon at Olympia. ${ }^{38}$

Emperors were linked both with male and female deities. Logically enough, goddesses are virtually always associated with female imperial figures. Hera is depicted on a coin of the Thessalian koinon which also depicts Livia, ${ }^{39}$ while at Athens

35. Egyptian gods appear on coins minted under several emperors; see e.g. RIC II, 444, $\mathrm{n}^{\circ} 826$ (Hadrian); III, 351, $\mathrm{nn}^{\circ}$ 1725-1726 (Faustina II); 436-437, $\mathrm{nn}^{\circ}$ 614a-b, 621 (Commodus); cf. also Dunand, 1973, III, p. 66 and n. 2. Emperors received dedications together with the Egyptian gods; see e.g. RICIS 618/1005 (Tomi): dedication of an altar to Serapis identified with Zeus Helios, his synnaoi theoi, the emperor Antoninus Pius and the Caesar Marcus Aurelius on behalf of an association of Alexandrians; RICIS 203/0701 (Phoinix, Crete): dedication (in latin) to Iuppiter Sol Optimus Maximus Sarapis, all the gods and Trajan by an imperial freedman (probably from Alexandria). In my opinion, the reference to the emperor in these cases seems more of an act of respect towards Rome than to indicate a connection of the Egyptian gods with the imperial cult. On the emperors' relationship with the Egyptian gods see Takàcs, 1995.

36. IvO 366 .

37. Cf. Hitzl, 1991, pp. 11-13; Hupfloher, 2006, p. 243; Camia, 2011, pp. 218-220; see also Vermaseren 1982, pp. 152-154, $\mathrm{n}^{\circ} 485$.

38. Cf. Burkert, 1985, pp. 177-178. For the combination between Cybele/Meter theon and the imperial cult in Asia Minor (at Pisidian Tymbriada and Galatian Pessinous) see Bru, 2016, pp. 61-63. On some imperial coins (RIC IV 564) the portrait of Iulia Domna on the obverse is associated with the image of enthroned Cybele accompanied by the inscription MATER DEUM at the reverse (cf. Bru, 2016, pp. 63 and 64, fig. 6).

39. RPC I 1427. 
Hadrian's wife Sabina may have been worshipped as Hera Panhellenia in the Panhellenion (the sanctuary of Zeus Panhellenios) alongside her husband, identified with Zeus Panhellenios. ${ }^{40}$ Still in Athens, Livia was worshipped on the Acropolis together with Augustus' daughter Iulia in connection with the goddess Hestia; ${ }^{41}$ Caligula's sister Drusilla was honoured as a new Aphrodite; ${ }^{42}$ Iulia Domna was assimilated to the patron goddess Athena Polias and worshipped as her synnaos. ${ }^{43}$ Moreover, as already noted, Augustus' spouse was assimilated to the Tyche of Gytheum and of the Eleutherolaconian koinon in the context of the Kaisareia, while at Tanagra Flavia Domitilla was honoured as Tyche (of the city) by her local priestess, ${ }^{44}$ and at Megara Hadrian's spouse Sabina was honoured as nea Demeter by the civic tribes. ${ }^{45}$

In a few other cases we find female deities connected not with a specific female imperial figure but with the emperors as a group. At Patrai, for example, the emperors may have been worshipped in connection with the cult of Artemis Laphria. The latter cult was introduced on the initiative of Augustus, who had the cult statue of the goddess (probably together with the entire temple) transferred from Aetolian Kalydon to the acropolis of the Roman colony. ${ }^{46}$ Even though there is no direct evidence for joint cult practices, the marked ideological significance of Augustus' act and the presence of a priestess of Diana Augusta Laphria who served also as priestess of the emperor ${ }^{47}$ suggest a possible connection with the imperial cult.

To sum up, it can be said that in Greece Roman emperors were usually linked with the main god(s) of each city. On the one hand this association fostered the integration into the Greek religious and symbolic system of the representatives of the new autocratic power the Greeks came to face. On the other hand, it did sometimes involve actual worship in the form of ritual practices in the context of a specific cult

40. Paus., I 18, 9; Cass. Dio, LXIX 16, 2; cf. Étienne, 2004, p. 203; Camia, 2011a, pp. 43-48.

41. IG II-III ${ }^{2}$ 5096; see infra, n. 91. Livia is probably also assimilated to Hestia Boulaia in a dedication from the Agora (SEG XXII 152); cf. Schmalz, 2009, p. 107, $\mathrm{n}^{\circ} 135$.

42. Agora XVIII, H257; cf. Kantirea, 2007, p. 72, n. 6; Schmalz, 2009, p. 111, nº 141.

43. IG II-III 1076 (with Oliver, 1940).

44. See supra, n. 27.

45. IG VII 73-74. The cult of Demeter at Megara was the oldest cult of the city. Hadrian too was honoured by the Megarian tribes as neos Pythios, as well as Olympios, Panhellenios, euergetes, tropheus, and nomothetes (IG VII 70-72). Cf. Camia, 2011a, pp. 74-75.

46. Paus., VII 18, 8-9; cf. Rizakis, 1995, pp. 167-171, n² 253; Kantirea, 2007, pp. 98-100; Rizakis, 2009, pp. 24-27.

47. Aequana Musa; cf. Rizakis, 1998, $\mathrm{n}^{\circ}$ 5. The epithet Augusta in association with Diana is also found on some coins of Patrai (see e.g. RPC I 1276). 
linked to a specific sanctuary and served by a priest. This leads us to consider the cultic implications of the association of Roman emperors with traditional gods.

\section{RITUAL PRACTICES FOR THE EMPERORS}

In Greece there are very few epigraphic texts that directly attest ritual practices such as sacrifices for the emperors or the domus Augusta in combination with traditional gods. One is the decree from Akraiphia already cited, which commemorates the consecration of an altar in the sanctuary of Zeus Soter to the emperor Nero identified with Zeus Eleutherios (from which we may infer that at least for a period he must have received sacrifices together with Zeus). ${ }^{48}$ Another is a fragmentary decree from Athens, dating to the Severan period, which attests to the identification of Julia Domna with Athena Polias. On the first day of each year according to the Roman calendar the polemarch, together with the priestess of the goddess, were to offer sacrifice to Julia Domna as mater castrorum; further sacrifices were to be offered annually by the archons to the city's Tyche on the occasion of the empress' birthday, while during the festival of Athena the chief state officials and all the priests were to celebrate libations and sacrifices for the goddess in order to manifest the piety of the polis towards the empress who acted as saviour of the Athenians. ${ }^{49}$

Specific terms may reveal a cultic connection between emperors and traditional gods. The verb $\sigma v \gamma \kappa \alpha \theta \imath \delta v^{\prime} \omega$ is attested with reference to emperor worship. In Athens, that the emperors were worshipped together with Zeus Eleutherios in the annexe behind the Stoa dedicated to that god in the Agora is confirmed by a fragmentary inscription, which records the setting up of a statue next to the statues of Zeus Eleutherios, other gods, and the emperor: [- - $\theta \varepsilon]$ ọic $\tau \tilde{\omega} \iota$ $\tau \varepsilon$ 'E $\lambda[\varepsilon v \theta \varepsilon \rho i \omega \iota$

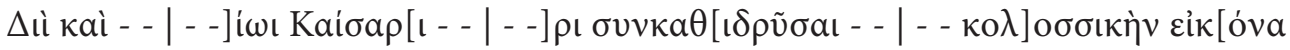
- - . ${ }^{50}$ An epithet with a similar meaning is used in the Athenian decree for Iulia Domna, cited above, with reference to the dedication of a cult statue (agalma) of the empress inside the Temple of Athena Polias so that she shall be oúvepovos of the patron goddess of Athens. ${ }^{51}$

48. See supra.

49. IG II-III ${ }^{2}$ 1076, with Oliver, 1940 (SEG XXXVII 97).

50. IG II-III ${ }^{2} 1081 / 5$, 1l. 4-7. The same verb is used, in the participle form, in a Milesian decree on the cults of Apollo Didymeus and Apollo Delphinios to indicate that the emperors were worshipped together with the main gods of the city (Milet I 3, 134, ll. 9-10).

51. IG II-III ${ }^{2} 1076$, 11. 19-20. The same epithet is used with reference to Hadrian to indicate his connection with the god Dionysus in an Ephesian inscription for the emperor on an altar dedicated by the 
Sacrifices and libations, however, are mostly attested by the altars dedicated to a specific emperor (or the Theoi Sebastoi as a whole) and a god, or to an emperor assimilated to a god. In these inscriptions the emperor's name is usually in the dative (or genitive) case, thus revealing the votive character of these dedications by contrast to the honorific character of the hundreds of imperial statues (with the name of the emperor in the accusative) set up in public locations. ${ }^{52}$

In Greece altars with dedications to a god and an emperor are scarce. Among the few examples one may cite are those to the Theoi Megaloi Patrooi and Augustus at Messene ${ }^{53}$ to the Muses, the Divus Caesar and Augustus identified with Apollo Mouseios at Megara, ${ }^{54}$ and to the Theoi Olympioi and Septimius Severus at Demetrias. ${ }^{55}$ Most altars were dedicated to the emperor alone, who may, however, be assimilated to a god (e.g. Antoninus Pius Zeus Eleutherios at Sparta; see supra) or may bear a divine epithet which de facto links him with a specific god. This is the case with the very numerous altars dedicated by Greek cities to Hadrian: in most cases the emperor bears the epithet Olympios, which is sometimes accompanied by other epithets such as soter, euergetes, or ktistes. Hadrian is the emperor most often represented among the imperial altars from the Greek world. ${ }^{56}$ One exceptional group stands out, from Athens, where over one hundred surviving altars are dedicated to Hadrian Olympios, soter and ktistes. ${ }^{57}$ The epithet Olympios, which is always present on the Athenian altars, creates a direct link with the highest Greek

mystai of a Dionysiac guild (I.Ephesos 275, 11. 6-7); cf. Frija, 2012, pp. 115-116. As noted by Frija, 2012, p. 116 the epithet homobomios is attested several times in connection with the imperial cult in Phrygia, but always for the Sebastoi worshipped on the same altar, not for the combination between an emperor and a traditional god. On the synnaoi theoi, Nock, 1930, is still fundamental.

52. It must be said that some of these altars might be purely honorific in character and have not been used for sacrifices or other ritual practices.

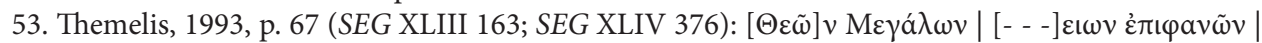

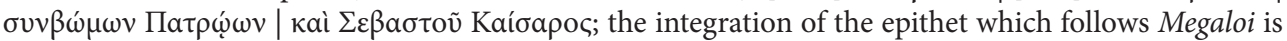
uncertain, various terms having been proposed (chthoneioi, Sebasmeioi, Karneioi): see Hoët-Van Cauwenberghe, 1999, pp. 177-179; Deshours, 2004, pp. 124-125; Kantirea, 2007, p. 133, n. 6; Galli and Tozzi, 2016, p. 253 , n. 54.

54. IG VII 36.

55. SEG XXV 680.

56. See Benjamin, 1963, pp. 74-83; Augustus was also the recipient of several altars, see e.g. for Athens Benjamin and Raubitscheck, 1959. Altars were also dedicated to the Sebastoi as a group (cf. Price, 1984, p. 216, n. 48).

57. Benjamin 1963, pp. 61-71, nn 1-95; Mitsos, M., in AD 17 (1961-1962), B, Chron., 28; SEG XLIV 166-167; Agora XVIII, H285-290 and 309. Cf. Camia, 2011a, pp. 36-39. In a few cases euergetes also occurs (IG II-III ${ }^{2} 3371$; SEG XLIV 167). 
deity (Zeus), whose imposing sanctuary Hadrian had finally completed. As is well known, he also created a new sanctuary for Zeus Panhellenios, which was not only the religious centre of a new Panhellenic "commonwealth" (Panhellenion) but also functioned as a sekos for the cult of the emperor, as is clearly stated by Cassius Dio (LXIX 16, 2). The dedication of (most of) the Athenian altars may, therefore, be linked to the third official visit of the philhellene emperor to the city, when the Olympieion was finally dedicated and the league of the Panhellenion was inaugurated in a solemn celebration. ${ }^{58}$ The latter event might have been also the occasion for the seven altars dedicated to Hadrian by Paleopolis of Andros, whose wording is similar to that of the Athenian altars. ${ }^{59}$

A similar circumstance may explain the approximately forty altars dedicated to Hadrian in Miletus in Asia Minor, a region that has produced many imperial altars, especially for this emperor. ${ }^{60}$ On these Milesian altars Hadrian bears the epithet Olympios, and in a few cases he is identified tout court with Zeus Olympios. ${ }^{61}$ Other epithets which occur are soter, oikistes (much rarer than the form $k t i s t e s$ found on the Hadrianic altars from elsewhere in the Empire $)^{62}$ and euergetes, while of the official imperial titulature only the terms Autokrator, Kaisar and Sebastos (as in the Athenian altars) are employed. The epithet Olympios indicates that the altars were dedicated in or after AD 129, when Hadrian visited the city; it is indeed probable that this visit prompted the dedication of (most of) the altars. ${ }^{63}$ Except for differences in the formulation, the context seems similar to that known for the altars for Hadrian Olympios from Athens: in both cases, the great number of items and the absence of a specific dedicant point to a public initiative prompted

58. Paus., I 18, 6; Cass. Dio, LXIX 16, 1-2; Philostr., VS 533; Hist. Aug., Hadr. 13, 6; cf. Benjamin, 1963, p. 60; Birley, 1997, p. 265; vd. infra, n. 69. The epithet Olympios is first attested in an Ephesian inscription (I.Ephesos 274) dated to the $13^{\text {th }}$ tribunicia potestas, i.e. between $10^{\text {th }}$ December 128 and $9^{\text {th }}$ December 129. Hadrian may have been first assigned this epithet in Athens during his second official visit on winter 128/9; cf. Birley, 1997, pp. 219-220, 222. For the possibility that the Nicopolitan altars for Hadrian Olympios date before Hadrian's second visit to Athens, see Cabanes, 1987, p. 167.

59. IG XII 5, 741-746; IG XII Suppl. 273; cf. Camia, 2011a, p. 39, n. 100. Hadrian is not known to have visited this small island nor to have benefited it in any way.

60. For a list of Hadrianic altars from Asia Minor see Benjamin, 1963, pp. 81-83.

61. Milet I.2, 21-23; Milet I.7, 290-297, 301; Milet VI.3, 1324-1349; IvDidyma 119; cf. I.Milet. VI.3, p. 200-201.

62. Milet VI.3, pp. 200-201.

63. Following on Rehm's view [Milet I.7, p. 350 (= Milet VI.1, p. 82); I.Didyma, p. 224 (ad n 356)], the editors of Milet VI.3 (p. 200), consider that there is a probable connection between Hadrian's visit to Milet in AD 129 (I.Didyma 254 and 356) and the dedication of the altars; cf. Halfmann, 1986, pp. 193, 204; Birley, 1997, p. 222. 
by some official occasion, while the differences in the physical characteristics of the altars and in the epithets seem to indicate that the material construction was left to private initiative. In this regard, one can furthermore imagine, on the basis of Hellenistic precedents, that the altars were located in a domestic context (in front of each house) so as to be used by citizens to offer libations at the passage of the imperial cortege ${ }^{64}$ Some of the Milesian altars were dedicated to Hadrian (Zeus) Olympios and Apollo Didymeus or Artemis Pythia respectively, i.e. the two main civic deities. ${ }^{65}$

Apart from Athens, further dedications to Hadrian Olympios on altars are also known from 'peripheral' areas of mainland Greece; on several altars from Nicopolis, for example, Hadrian is styled Olympios and is identified with Zeus Dodonaios, while his wife Sabina also received altars (as Artemis Kelkaia). ${ }^{66}$ The epithet Olympios is not always present. On about thirty altars from Sparta dedicated to him, Hadrian does not bear a divine epithet, being (only) mentioned as soter (as well as, in a few cases, $k$ tistes and/or euergetes) ${ }^{67}$ This may simply be due to the fact that these altars were probably dedicated before Hadrian's adoption of the epithet Olympios (AD 128/129), if not on the occasion of Hadrian's first official visit to Sparta (AD 124/125) as suggested by Jean Bingen on the basis of the only altar with any indication of chronology, ${ }^{68}$ in any case before the final dedication of the Olympieion

64. According to A. Rehm, Milet I.7, p. 350 (= Milet VI.1, p. 82), "Es sieht aus, als habe einmal in jedem milesischen Bürgerhaus ein solcher Altar gestanden"; many Milesian altars were found in the area of the South Market. Altars were found inside houses at Pergamum and Ephesus (Price, 1984, p. 112, n. 75). An imperial altar was found in situ in front of a house's entrance at Ptolemais in Cyrenaica (Kraeling, 1962, p. 209, $\mathrm{n}^{\circ}$ 1). The Athenian altars for Hadrian were found (albeit not in situ) in several parts of the city, almost a third of them coming from the Agora (Agora XVIII, H285-313, and pp. 144-145). For the Hellenistic precedents see Robert, 1966, pp. 186-187, 190-191.

65. See e.g. Milet I.7, 301-302; Milet VI.3, 1332-1333. Other conspicuous groups of altars dedicated to Hadrian, who in most cases is styled Olympios, are those from Pergamum (I.Pergamon 364-374) and Ephesus (I.Ephesos 267-271A, 271E, 272-273).

66. Samsaris, 1994, pp. 63-64 and 159-168, nn 11-15, 18-21; SEG XLIII 343; cf. Cabanes, 1987. For further Hadrianic altars from mainland Greece see Benjamin, 1963, pp. 74-77; Camia, 2011a, pp. 252262 (passim).

67. IG V 1, 381-404 and 1592; Euangelidis, 1911, p. 198, n 5; SEG XI 763; SEG XIII 256; SEG XXXVI 358; see also SEG XLIX 400; cf. Camia, 2011a, pp. 66-67.

68. Bingen, 1953, pp. 642-646, $\mathrm{n}^{\circ} 25$ (SEG XIII 256): dedicated by the synarchia serving under P. Memmius Sidectas; cf. Benjamin, 1963, p. 76; Cartledge and Spawforth, 2002, p. 108. On Sidectas see Rizakis, Zoumbaki, and Lepenioti, 2004, LAC 579. On the chronology of Spartan altars see most recently Cortés Copete, 2017, who after noting that it is not possible to refer Sidectas' year to Hadrian's first or second visit to Sparta, remarks that "it would make more sense to attribute a later date to these altars, one connected with Hadrian's religious policy tour between AD 128/129 and 131/132, the date of the

ARYS, 16, 2018 [105-137] ISSN 1575-166X 
sanctuary in Athens, which reinforced the privileged relationship between Hadrian and the supreme Greek god. ${ }^{69}$ Spartans, however, do not seem to have lacked occasions for associating the emperor with a specific god, as is shown by a second, more numerous, series of altars, which have already been cited several times, dedicated to Antoninus Pius: on them Antoninus is identified with Zeus Eleutherios, despite the fact that he is not known to have ever visited Sparta, and no particular benefaction by himself towards the city is attested..$^{70}$ In fact, A. Hupfloher has interpreted this second series as attesting the celebration of an adventus ritual first performed for Hadrian's visit, which would have been maintained under his successor. She also notes that on one of these altars Antoninus is identified with Zeus Eleutherios and Olympios, ${ }^{71}$ which, to follow up her suggestion, might hint at the celebration of rituals for Hadrian in association with Zeus Olympios. ${ }^{72}$ If we cannot state with certainty that Spartan citizens actually sacrificed to Hadrian on those altars in association with Zeus, it is nonetheless possible to suggest a cultic connection between Hadrian and the god based on an important inscription dated to after Hadrian's second visit to Greece (AD 128/129), namely the cursus of the Spartan notable C. Iulius Theophrastus, who among many offices was also hiereus of Zeus Olympios. During his tenure, he dedicated two statues, one of the Demos of the Spartans, the other of "Hadrian among the gods". ${ }^{73}$ The cult of Zeus Olympios is also attested at

majority of the altars the Greek cities dedicated to the emperor in Athens" (p. 119). Unlike most of the items from the most conspicuous groups of imperial altars for Hadrian from the Greek world, however, the Spartan ones lack exactly the epithet Olympios; this would seem to indicate that, even though one prefers to refer them to Hadrian's second visit to Sparta (AD 128/9), the altars were probably dedicated before the official assumption (perhaps in Athens in the winter of that year) of the epithet Olympios (see supra, n. 58).

69. For the final dedication of the Athenian Olympieion in the same year of the foundation of the Panhellenion during Hadrian's third visit to Athens (AD 131/132), contrary to the testimony of HA, Hadr. 13, 1-6 (cf. Weber, 1907, p. 210; Graindor, 1934, p. 42; Follet, 1976, pp. 114-116 and 346), see the Epidaurian inscription $I G \mathrm{IV}^{2} 384$ (= Oliver, 1970, $\mathrm{n}^{\circ} 38$ ) which establishes a fundamental synchronism between the third year following the consecration of the temple of Zeus Olympios and the foundation of the Panhellenion on the one hand, and the tenth year since Hadrian's first visit to Greece on the other. Cf. Birley, 1997, p. 265: "It is difficult to avoid the conclusion that the dedication of the Olympieion and the launching of the Panhellenic organisation were one and the same occasion".

70. IG V 1, 403, 407-445; SEG XI 766-768; SEG XXXVI 359; SEG XLI 316; SEG XLIV 359; SEG XLVII 360-361; SEG XLIX 402-404; cf. most recently Camia, 2011a, pp. 77-78.

71. IG V 1, 445.

72. Hupfloher, 2000, pp. 160 and 172-173.

73. SEG XI 492, 1l. 2-4. For a Hadrianic chronology of the inscription, usually held to belong to the Antonine period (cf. Cartledge and Spawforth, 2002, pp. 109-110) see most recently Cortés Copete,

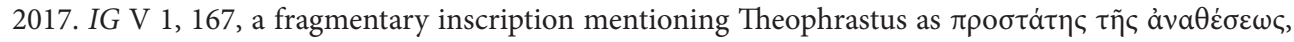


Sparta by Pausanias' reference to a hieron of this god (Paus., III 14, 5) and by an altar dedicated to Zeus Soter Olympios, a formulation that already A. Boeckh suspected might refer to Hadrian. ${ }^{74}$ If a cult of Zeus Olympios did not already exist at Sparta, its institution may have been prompted, perhaps on Theophrastus' initiative, by Spartans' desire to pay homage to Hadrian together with the supreme Greek god following the dedication of the Athenian Olympieion. ${ }^{75}$ If so, the altars for Hadrian, on which he does not bear the epithet Olympios, should be dated before the institution of this new (joint?) cult.

\section{JOINT PRIESTHOODS}

Assimilation between emperor and god can be revealed by a joint priesthood. The presence of a priest serving both the imperial and a traditional cult may sometimes point to the existence in a given city of a joint cult of an emperor and a god. It is not always possible to distinguish between a simple accumulation of several priesthoods (a phenomenon that becomes increasingly common already in the Hellenistic period) and a true joint priesthood. However, the epigraphic formulation can be of some help: generally speaking, it can be said that the repetition of the priestly title (hiereus or other) usually indicates cumulation of more than one priesthood, whereas when a single priestly title is connected by the genitive case to two (or more) divine subjects (scil. the emperor and a traditional god), this is usually an indication of a joint priesthood. Moreover, some sort of cultic connection between emperor and god can also be revealed by the priesthood of an emperor who is identified with a god or bears a divine epithet.

The number of known joint priesthoods in "old" Greece is very small. In Athens, as we have seen, a seat of the theatre of Dionysus dated to the Augustan period was reserved for the hiereia of Hestia on the Acropolis, Livia and Iulia (the daughter of Augustus), ${ }^{76}$ while an archiereus of Nero and Zeus Eleutherios is attes-

might refer to the consecration of the same sculpture group recorded in SEG XI 492 (cf. Cortés Copete, 2017, p. 120).

74. IG V 1, 406; Boeckh (CIG 1312): "haud dubie Hadriani Olympii”; Boeckh's view is backed up most recently by Cortés Copete, 2017, pp. 119-120, who connects both this monument and the temple mentioned by Pausanias with Theophrastus' role as priest of Zeus Olympios, and further suggests that the statue of Hadrian dedicated by Theophrastus could have been part of a sculpture group including "other gods, perhaps the Olympians".

75. Cf. Cartledge and Spawforth, 2002, pp. 109-110; contra Hupfloher, 2000, p. 160 (and n. 4).

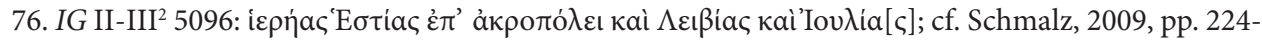
$225, n^{\circ} 297$.

ARYS, 16, 2018 [105-137] ISSN 1575-166x 
ted once in the context of the "koinon of the Hellenes". ${ }^{77}$ As for priests of an emperor identified with a god or bearing a divine epithet, one can cite two cases which both refer to Hadrian: the hiereus of Hadrian Eleuthereus, attested once on a seat of the theatre of Dionysus ${ }^{78}$ - the particular epithet links the emperor with the god that was worshipped in the sanctuary located next to the theatre; and the hiereus of (theos) Hadrian Panhellenios, who served the cult of the emperor in combination with that of Zeus in the Athenian Panhellenion. ${ }^{79}$ There are also two rather special cases, likewise from Athens. A seat in the theatre of Dionsyus was reserved for the priest of the Demos, the Charites and the goddess Roma, while an Eleusinian inscription dated to the first half of the first century $\mathrm{AD}$ reveals the existence of a hiereus of the Senatus Romanus, the Demos and the Charites. ${ }^{80}$

Apart from the priests of Hadrian Eleuthereus and Panhellenios, no more priests of an emperor and a god (or of an emperor bearing a divine epithet) are known to me from "old" Greece except for the archiereus of Nero and Zeus Eleutherios cited above. ${ }^{81}$ This situation is largely a consequence of the evolution of the imperial priesthood in Greece towards collective priesthoods of the Sebasto $i$, a general trend which is reflected in the crystallisation of the priestly titulature in the form "archiereus of the Sebastoi". ${ }^{82}$ Inscriptions furthermore show that it was very unusual in priestly titulature to combine reference to the Sebastoi as a group with traditional gods. The sole example in Greece itself is a certain Lykos, strategos of the Thessalian koinon, who was hiereus of the Sebastoi and Zeus Karaios, besides serving as hiereus of the Sebastoi, Zeus Soter and Athena at his hometown Hypata. ${ }^{83}$ A few more examples are known from the cities of Asia Minor: archiereus of the patrioi theo $i$ and the Sebastoi (Magnesia on the Maeander); ${ }^{84}$

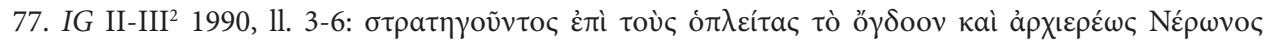

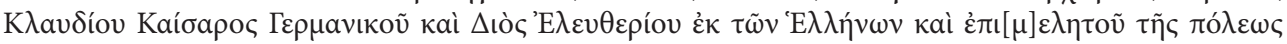

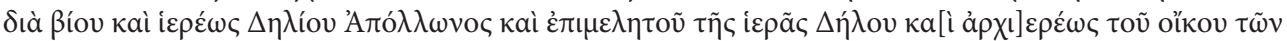

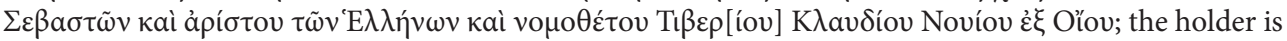
the Athenian aristocrat Ti. Claudius Novius of Oion [Byrne, 2003, Claudii (p. 213)]. On the cult of Zeus Eleutherios (and Homonoia) celebrated at Plataea by the koinon of the Hellenes cf. Schachter, 1981-1994, 3, pp. 125-143.

78. IG II-III ${ }^{2}$ 5035; cf. Maas, 1972, pp. 116-117.

79. See e.g. Corinth VIII.1, 80 (1l. 4-5); cf. Camia, 2011a, pp. 44-46.

80. IG II-III ${ }^{2}$ 5047; I.Eleusis 333.

81. See supra, n. 77.

82. Camia, 2017.

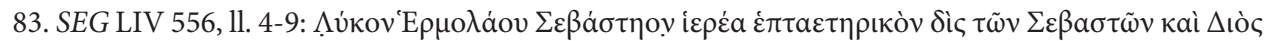

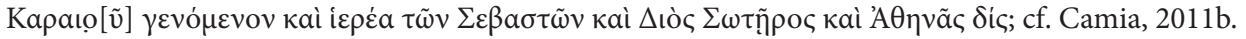

84. I.Magnesia 113 (reign of Claudius); cf. Frija, 2012, p. 239, nº 137. 
hiereus of Zeus Idaios and the Sebastoi (Skepsis); ${ }^{85}$ and hiereus of Apollo and the Theoi Sebastoi (Kos). ${ }^{86}$ Even considering these cases, however, in Asia Minor too the number of joint priesthoods linking imperial cult and traditional cults is quite small. Indeed, mutatis mutandis, the epigraphic evidence from Asia Minor confirms the impression we have from the cities of "old" Greece with regard to the percentage and chronological trend of the priesthoods that combine imperial cult and traditional cults. In her work on the civic priests of the imperial cult in the Roman province of Asia, Gabrielle Frija lists about twenty such cases, almost all of them dating to the Julio-Claudian period. She cites only one case dated to the second century (T. Statilius Criton at Ephesus, hiereus of the Anaktores, Alexander the Great and Augustus' nephews Gaius and Lucius) ${ }^{87}$ and another possible case from the third century ${ }^{88}$ Frija links the gradual disappearance of joint priesthoods during the High Empire to the proliferation of independent civic priesthoods of the imperial cult. Cults of the emperors in association with traditional gods do not disappear, but they are not served by a joint priesthood. In this regard, it must be noted that the cult of an emperor together with a traditional god may well have been served by the priest of the latter god. This seems for example to have been the case with the cult of Hadrian in the sanctuary of Zeus Olympios at Athens: there is no trace in the epigraphic evidence of a priest either of Hadrian and Zeus Olympios or of Hadrian Olympios, and this may be explained by the fact that this cult was probably served by the hiereus of Zeus Olympios. ${ }^{89}$

As for the motives behind the institution of a joint priesthood "emperor + god", the epigraphic evidence from Asia Minor, richer than that from mainland Greece, provides some help. According to Frija, the main motives for the institution of a priesthood of the emperor and a god were a) some form of congruence perceived between the traditional deity and the emperor; b) a desire to range the emperor with the main (patron) god(s) of the city, independent of the specific qualities of that deity/those deities. As for those few cases that fall in neither of these categories, they can be explained as the result of the personal initiative of members

85. IGRR IV 229 (end of the first century AD?); Frija, 2012, p. 118 and n. 20.

86. Jacopi, 1932, p. 213, n 51 (reign of Claudius or Nero); cf. Frija, 2012, p. 117 and n. 13.

87. I.Ephesos 719 (reign of Trajan), 11. 8-10; Frija, 2012, p. 117 and n. 17.

88. At Akmonia the hiereus Aurelius Polyneices dedicated an altar to Dionysus and Severus Alexander (MAMA 6, 240), yet he may have been priest only of the god (cf. Frija, 2012, p. 120).

89. IG II-III 3687 (1l. 6-7), 5025; I.Eleusis 633; IG IV² 691. 
of families that controlled a specific cult and its priesthood. ${ }^{90}$ The few cases from the cities of "old" Greece fit in this model. Hestia, the divine personification of the common hearth symbolizing the unity of the civic community, was combined with Livia, the wife of Augustus and mother of Tiberius, symbolizing the unity of the gens Iulia and more generally of the Empire. ${ }^{91}$ Nero, liberator of Greece, was linked with Zeus Eleutherios in the context of the "koinon of the Hellenes", which at Plataea went on celebrating the Greeks' victories over the Persians in the early fifth century BC. Hadrian, the founder of the Panhellenion, was worshipped together with the supreme panhellenic god, as well as with Dionysos; the links with the latter god are testified by the close relationship with the Athenian synod of the Dionysiac technitai. ${ }^{92}$ As for the two imperial priesthoods held by the Thessalian Lykos, Zeus and Athena were probably (among) the main deities of his hometown Hypata, although it remains uncertain what exactly the link between the imperial cult and Zeus Karaios might have been. ${ }^{93}$

\section{Priests as CUltic “ACtors”}

The main duties of priests of the imperial cult must have concerned the general supervision as well as participation in the funding of the rituals and cult celebrations for the emperors. ${ }^{94}$ Specific evidence, however, particularly with regard to ritual practices such as sacrifices and libations, is scarce, especially for "old" Greece.

\footnotetext{
90. Frija, 2012, pp. 117-119.
}

91. Cf. Schmalz, 2009, pp. 224-225, n 297. Kajava, 2001, p. 72, identifies the Hestia on the Acropolis with the Roman Vesta and states that it represents the "transfer (or rather a duplication) of a Roman cult in the Greek soil". By contrast, for Kantirea, 2007, pp. 127-129, the cult of Hestia on the Acropolis is a local (Athenian) cult instituted on the model of the Roman cult of Vesta; in her opinion the new cult was established following Augustus' decision to include a temple of Vesta inside his residence on the Palatine hill and to dedicate an altar to the goddess in his house. It might be worth noting that Livia acquired the privilege to sit at theatre among the Vestal Virgins (cf. Tac., Ann. IV 16, 4); according to Kearsley, 2005, p. 110 "Livia's 'Vestal' qualities were acknowledged in the East by the honouring of her as Hestia"; for the identification of Livia with Hestia in the Greek East see I.Ephesos 859A; I.Lampsakos 11; cf. Hahn, 1994, pp. 44-45.

92. Geagan, 1972.

93. Photius' Lexicon, s.v. Kapaı́c (Theodoridis, 1998, p. 189) reports that the cult of Zeus Kapaı́c was celebrated in Thessaly and in Boeotia.

94. According to Frija, 2012, pp. 145 and 148 a variety of different types of sources shows that the usual features of civic cults (namely sacrifices and prayers) must have been an integral part of the common duties of the priests of the imperial cult. 
Among the approximately 250 epigraphic occurrences of priests of the imperial cult from the province of Achaia, rituals are virtually never mentioned. ${ }^{95}$ One of the rare exceptions is a fragmentary decree of $\mathrm{AD} 15$ from Messene, that is, shortly after the accession of Tiberius. ${ }^{96}$ It provides the partial, yet significant, description of a three-day festival for the divus Augustus, the emperor Tiberius and other members of the imperial family. The celebrations include a procession led by the annual hiereus of Augustus to the Sebasteion, where lambs were sacrificed, and athletic and equestrian agones to be held on the occasion of the dies natalis; ${ }^{97}$ reference is also made to torches used by the priest perhaps to illuminate ( $\varphi \omega \tau i \sigma a l)$ imperial images. ${ }^{98}$ Most of the epigraphic evidence concerning priests of the imperial cult, however, consists of honorary inscriptions which simply mention the office, sometimes in addition to other religious or political positions. ${ }^{99}$ Inscriptions usually refer much less to sacrifices and other ritual practices than to the organization of festivals or the dedication of imperial statues and buildings. In other words, they tend to underline priests' munificence as public officials rather than their practical functions in connection with the rituals of emperor worship.

This point also holds true for those few epigraphic texts which do provide some details of the ritual proceedings, such as the honorary decree voted in $\mathrm{AD} 1$

95. The same holds true for the cities of Asia Minor, even though there are a few more examples on specific cult rituals performed by priests of the imperial cult. See e.g. IAph2007 12.206 (Aphrodisias), 11. 6-9: a high priest of the emperors and stephanephoros performed sacrifices to the ancestral gods, offering them prayers for the health, safety, and eternal power of the emperors (cf. Frija, 2012, p. 146 and n. 135); MAMA VIII 492b (Aphrodisias), 11. 8-14: a priestess of the emperors, who had also assumed other offices, sacrificed every year for the emperors' well-being; I.Pergamon 523 (Antonine), 11. 15-16: Claudia Femia, the hiereia of the thea Faustina, offered a two-day bullfight.

96. SEG XLI 328; cf. Kantirea, 2007, pp. 69-71 and 206-207, n 3; Galli and Tozzi, 2016, p. 254 (and n. 55).

97. Either of Tiberius or Augustus (cf. $A E$ 1991, $\mathrm{n}^{\circ}$ 1442). The same festival may be alluded to in a honorary decree dated $\mathrm{AD}$ 2/3 for the quaestor pro praetore P. Cornelius Scipio, who had celebrated and financed the Kaisareia at Messene, at the same time promoting its celebration in most of the other cities of the province of Achaia (SEG XXIII 206, 1l. 7-10); cf. Herz, 1993; Kantirea, 2007, pp. 162 and 208, ${ }^{\circ}$ 1; Camia, 2011a, p. 122; Galli and Tozzi, 2016, p. 255. Three other (fragmentary) honorary decrees from Messene are known relating to the same man (SEG LXIII 289/290).

98. SEG XLI 328, 1. 25; this feature can be connected with the celebration of imperial mysteries; see Pleket, 1965, pp. 342-344.

99. Cf. Frija, 2012, p. 150 : “les inscriptions sont peu précise sur les activités proprement rituelles des prêtres des empereurs et soulignent bien davantage leur générosité dans les distributions ou l'organisation des spectacles". 
by the city of Kalindoia in Macedonia (Mygdonia). ${ }^{100}$ Since it is one of the earliest attestations of emperor worship in the Greek peninsula, it is hardly to be wondered at that this decree also provides details of the ritual practices (namely sacrifices) that were performed - such matters were later probably regarded as routine, just like other ritual details. The honorand, Apollonios son of Apollonios, had voluntarily assumed the joint priesthood of Zeus, Roma and Augustus in his hometown. ${ }^{101}$ The motivation clause of the honorary decree highlights the multiplicity of Apollonios' activities, stressing in particular his generosity, which relieved his city of onerous expenditures connected with the celebration of the emperor. ${ }^{102}$ For an entire year (probably the term of his priestly office), Apollonios had provided at his own expense for the public monthly sacrifices to Zeus and Augustus, thus ensuring the proper honours to the gods as well as food for his fellow-citizens. ${ }^{103}$ In the context of the panegyris Apollonios offered banquets to the whole population and prepared a sumptuous procession. ${ }^{104} \mathrm{He}$ also organized and most likely financed lavish contests for Zeus and Augustus. ${ }^{105}$ Furthermore, Apollonios made splendid money distributions to the city's constituent tribes. ${ }^{106}$ Finally, he dedicated at his own expense a cult statue (agalma) of Augustus, which is characterized in the text as an "eternal memorial to the emperor's benevolence towards the whole human race"; in that way Apollonios dispensed honours to the gods (including the emperor) and ornamented his city. ${ }^{107}$ Apollonios' generosity and devotion to his motherland

100. Sismanidis, 1983 (SEG XXXV 744) (= Adam-Veleni, 2008, p. 109, n 8); see most recently G. Tozzi in Galli and Tozzi, 2016, pp. 245-256. In the same locality the remains of a building complex identified with a Sebasteion have been unearthed; see Sismanidis, 2003; Sismanidis, 2005; Sismanidis, 2009, pp. 322-328; see also Adam-Veleni, 2008, pp. 123-168 and most recently M. Galli in Galli and Tozzi, 2016, pp. 239-245.

101. The same priesthood appears in the eponymous formula of a building inscription which was found in front of one of the rooms of the Sebasteion (SEG LVIII 578). The date (AD 88) suggested by the first editor, K. Sismanidis (in Adam-Veleni, 2008, $\mathrm{n}^{\circ}$ 32), has however been challenged by Prignitz, 2011, who thinks that the year ' 120 ' mentioned at the beginning of the inscription refers not to the Actian era but to the Macedonian era, and accordingly dates the inscription to $27 \mathrm{BC}$.

102. Sismanidis, 1983, p. 77, 11. 5-15.

103. Ibidem, ll. 15-19, 26-30.

104. Ibidem, 11. 19-22, 30-31; he invited to the banquet both the population as a whole and the individual citizens in the dining halls (ll. 20 and 31: trikleina) inside the Sebasteion.

105. Ibidem, 11. 22-23.

106. Ibidem, 11. 32-33.

107. Ibidem, 1l. 35-39. This statue is probably to be identified with the cuirassed marble imperial portrait found in 1961 at Kalamotos, for which see Karanastasi, 1995, pp. 215-221, e fig. 58a; cf. also Hupfloher, 2006, p. 251, and n. 70; Galli and Tozzi, 2016, p. 241, n. 10. 
were such that he himself covered the expense of the honours decreed for him by the polis, including three statues for himself and his parents to be set up in the most prominent spot of the agora. ${ }^{108}$ This text shows well that emperor cult in the Greek world shared the main features of traditional cults: as a priest of Augustus, Apollonios organized and financed a festival including a procession, sacrifices and agones, and he also dedicated a cult statue of the emperor, ${ }^{109}$ which was probably set up inside the Sebasteion that has been unearthed at Kalindoia.

Besides being one of the few relatively detailed accounts from the Greek world on ritual practices performed by priests of the imperial cult, the decree from Kalindoia also represents one of the very few cases that concern a joint priesthood of the emperor and a traditional god. A few further cases are known from the cities of Asia Minor. At Kys (Caria), for example, at the middle of the first century AD the stephanephoros and hiereus of the divus Augustus and Zeus Eleutherios sacrificed to the gods and the theoi Sebastoi for the eternal preservation and well-being of the divine house. ${ }^{110}$ On the other hand, rituals could be performed by a priest of the imperial cult for the emperors and a traditional god. At Kos, for example, at the middle of the first century AD the hiereus of the imperial cult L. Nonius Aristodamus sacrificed to the Sebastoi and the other gods. ${ }^{111}$

The scarcity of epigraphic testimonies on the ritual duties of imperial priests must not lead one to doubt either these priests' involvement with ritual matters nor, more generally, the cultic nature of emperor worship. As has been pointed out by G. Frija, "dans la question du statut des empereurs divinisés, c'est moins la fonction du sacrifiant qui compte que la nature du rite pratiqué". ${ }^{112}$ In this regard it is worth noting that ceremonies and rituals connected with emperor worship could also be performed by other priests. The sacrifices that the empress Iulia Domna received in Athens as mater castrorum in the first day of the Roman year, already re-

108. Sismanidis, 1983, p. 77, 11. 39-51. It is worth noting en passant that the same term (agalma) employed to characterize the cult statue of Augustus is also used for the three honorary statues (cf. Koonce, 1988); see also, most recently, Ma, 2013, p. 2.

109. Who in the inscription is significantly put on the same level with the gods (see $11.14,17,38$ ).

110. Frija, 2012, p. 147 and n. 137.

111. Maiuri, 1925, n 462, ll. 5-6; cf. Price, 1984, p. 211. See also IG XII 2, 58 (= OGIS 456 = IGRR IV 39): fragmentary decree of $27 \mathrm{BC}$ from Mytilene mentioning a penteteric thymelic contest, annual sacrifices in the temples of Zeus and of Augustus, and monthly sacrifices to Augustus on his dies natalis, which were modelled on the sacrifices offered to Zeus; among the functionaries responsible for the provision of the sacrificial victims is a high priest; cf. Fishwick, 1987-2004, pp. 171-172; Price, 1984, pp. 217-219; Frija, 2012, pp. 145-146.

112. Frija, 2012, p. 149.

ARYS, 16, 2018 [105-137] ISSN 1575-166X 
ferred to above, were presided over by the priestess of Athena Polias, who received as honorarium a portion of the sacrificial meat. ${ }^{113}$ Still at Athens, as we have seen, it was probably the priest of Zeus Olympios who supervised the worship Hadrian received in the Olympieion.

Civic magistrates too could perform sacrifices to (or for) the emperors as well. The famous hieros nomos on the cult of the emperors from the Laconian city of Gytheum provides that during the procession the ephors shall sacrifice a bull in the Kaisareion for the well-being of the emperors and the eternal preservation of their power, as well as requiring the other magistrates to sacrifice in the agora; furthermore, the synedroi (probably the council members) and all the civic magistrates shall burn incense for the emperor's well-being in the theatre in front of the imperial images of the divus Augustus, the emperor Tiberius and Livia before the spectacles begin. ${ }^{114}$ At Akraiphia, on the other hand, the benefactor Epaminondas, while serving as agonothetes, sacrificed a bull to Hermes, Heracles and the Sebastoi after re-founding the traditional Ptoian festival with the new name Megala Ptoia kai Kaisareia sometime before the middle of the first century AD; Epaminondas also offered other sacrifices to the Sebastoi upon assuming the supreme civic magistracy, as well as to the gods and the Sebastoi in the sanctuary of Apollo during the festival. ${ }^{115}$

113. IG II-III ${ }^{2}$ 1076, with Oliver, 1940; cf. Price, 1984, p. 217. At Lagina (Stratonicea) husband and wife, both of them priests of Hekate, gave money to their fellow citizens so that the latter could perform sacrifices for the imperial house and Hekate (I.Stratonikeia 662, esp. col. a, 1l. 2-4; cf. Frija, 2012, p. 146).

114. SEG XI 923, 1l. 4-7, 28-30; Kantirea, 2007, pp. 65-69 and 204, n 2a; Camia, 2011a, pp. 86-87, and most recently Galli and Tozzi, 2016, pp. 255-256. The function of "hiereus of the divus Augustus" is mentioned in the inscription in an eponymous formula dating the tenure of the ephors charged for the provision of the imperial images (SEG XI 923, 11. 33-36); the same individual was holding the charge of strategos, which may be referred to the koinon of the Eleutherolakones (the latter supra-civic organisation may have "sponsored", if not controlled at all, the imperial festival celebrated at Gytheum, which is probably identical with the Kaisareia attested by $I G \mathrm{~V} 1,1167)$.

115. IG VII 2712, 11. 22-23, 29-31, 67-68. At Akraphia joint sacrifices to the emperor Claudius and Apollo Ptoios are also attested (SEG XV 330, 11. 11-14). A close interconnection existed between the priesthood of the imperial cult and the agonothesia of imperial festivals, as is shown e.g. by the titulature of the priestly functions held (most likely at Thessalian Hypata) by L. Cassius Petraeus (IG IX 2,

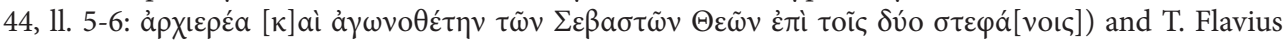

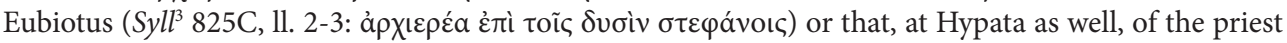

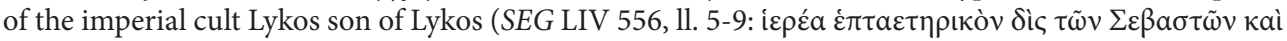
$\Delta$ ı̀̀ Kapaıo[ṽ]); cf. Robert, 1940, p. 193 and n. 5; Camia, 2011b). Rituals for the emperors celebrated by magistrates are also known from Asia Minor: for example, at Kyme during the Kaisareia a prytanis offered sacrifices to Augustus, his adoptive sons Gaius and Lucius, and the other gods (SEG XXXII 1243, 


\section{EPILOGUE}

In the Greek cities of the Roman Empire emperors were often honoured and worshipped in combination with traditional gods. Not only were they worshipped in pre-existing cult places and within the context of traditional religious festivals, but they were also assimilated either verbally or iconographically with the gods in inscriptions, coins and statues. Joint priesthoods of the emperor(s) and the gods are also attested.

The case study (mainland Greece) analysed in this paper shows that this practice responds to different motivations. It was a way to pay a special homage to emperors by linking them with the gods that Greeks had worshipped immemorially. At the same time it enabled the (elites of) Greek cities to establish a subtle hierarchy between emperors and gods. In fact, emperors were not always set on a par with the traditional gods, the assimilation not always (or only apparently) amounting to a full equivalence between god and emperor. Indeed, some cases are ambiguous, which may have been sought for purposely in order to not elevate the emperors too overtly. On the other hand, integrating the emperors into the traditional Greek pantheon was a means of finding them a place in the Greeks' symbolic universe. In that way the subjects of the empire could come to term with the autocratic power of their new overlords in a more familiar fashion and according to their cultural horizon.

The assimilation of emperors to gods, however, was not solely pragmatic. Ritual practices are attested in the Greek cities for the emperors together with the gods of the civic pantheons, though it is not easy to identify them in the evidence. Rituals such as sacrifices for the emperors may have been performed in pre-existing temples or sanctuaries in the context of traditional festivals to which emperors had been associated; yet the consecration of a building to the emperor or the latter's integration into a traditional festival did not invariably imply cult practices. Priests combining in their titulature the emperor and a god may be expected to have performed rituals for both; yet not only are such priesthoods rarely attested in Greece, but, more generally, there are very few attestations of cult ceremonies performed by priests of the imperial cult.

Ritual practices in this context are mostly attested by altars dedicated to the emperors. Monument and inscription typology - a dedication, as indicated by the name of the emperor in the dative or genitive case - suggest that these altars were

11. 41-45); at Keramos the stephanephoros took care of the celebrations of the imperial cult (I.Keramos 14; cf. Frija, 2012, p. 147 and n. 136). 
used to offer sacrifices and libations, sometimes on the occasion of the emperor's visit to a city. In the Greek world most imperial altars were dedicated to Hadrian, who in many ways fostered his connection with the gods of the Greek pantheon and in particular with the supreme god Zeus Olympios, to whom he was linked by the special relationship which is marked by the assumption of the epithet Olympios. The presence of a divine epithet next to the name of the emperor confirms the cultic character of such altars. It must however be emphasized that altars dedicated both to a god and the emperor are few and far between, at least in mainland Greece. Far more common are altars (not only for Hadrian) with dedications to the emperor either linked or assimilated tout court with a traditional god through the attribution of a god's identity (e.g. Antoninus Pius Zeus Eleutherios), a divine epithet (e.g. Hadrian Olympios) or the expression neos followed by the god's name (e.g. Hadrian neos Dionysos). This difference may reflect a hierarchical approach to the divinity of the emperors. On the one hand the representatives of the new imperial power were treated as gods, being honoured with named priesthoods, cult places, and festivals with the usual rituals, in other words all the main institutional features of traditional cults. On the other hand a subtle difference was probably recognised between these new gods and the Greeks' old gods, a difference hinted at by these very institutional measures: even though emperors were assimilated to gods, associated with their qualities or considered to be a new manifestation of a given god, and were indeed actually worshipped like gods, nonetheless they were not perceived as completely equal to the old gods of the Greek pantheon. ${ }^{116}$

116. These two statements (worship of Roman emperors like gods and recognition of a hierarchy between them and the traditional gods) are not in contrast to each other: while performing sacrifices and other rituals for the emperor on the model of the traditional cults, priests of the imperial cult, who usually belonged to the civic elites, were perfectly aware of this status difference, which they may also have fostered in a way. It is worth noting that this "critical attitude" towards rulers is not specific of mainland Greece during the Roman imperial period, since mutatis mutandis it can be applied both to other areas of the Greek world and to the relationship between Hellenistic rulers and Greek cities. 


\section{BIBLIOGRAPHY}

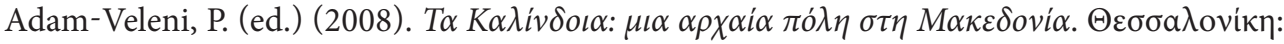

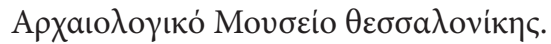

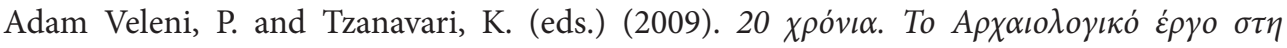

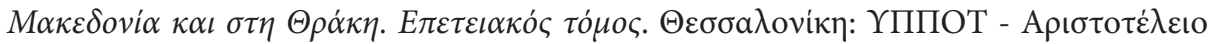

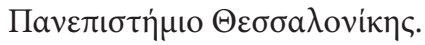

Aleshire, S.B. (1989). The Athenian Asklepieion: the People, their Dedications and the Inventories. Amsterdam: J. C. Gieben.

Baglioni, I. (ed.) (2016). Saeculum aureum: tradizione e innovazione nella religione romana di epoca augustea. Roma: Quasar.

Baldassarri, P. (1998). $\Sigma E B A \Sigma T \Omega I \Sigma \Omega T H P I$. Edilizia monumentale ad Atene durante il saeculum augustum. Roma: G. Bretschneider.

Bardani, V.N. (1988). Eic IG V 1, 1462. Horos, 6, pp. 79-81.

Benjamin, A. (1963). The altars of Hadrian in Athens and Hadrian's Panhellenic Program. Hesperia, 32, pp. 57-86.

Benjamin, A. and Raubitschek, A.E. (1959). Arae Augusti. Hesperia, 28, pp. 65-85.

Bingen, J. (1953). Inscriptions du Péloponnèse. Bulletin de Correspondance Hellénique, 77, pp. 616-646.

Birley, A.R. (1997). Hadrian. The restless emperor. London and New York: Routledge.

Bremmer, J.N. and Erskine, A. (eds.) (2010), The Gods of Ancient Greece. Identities and Transformations, Edinburgh.

Bringmann, K. and Von Steuben, H. (eds.) (1995). Schenkungen hellenistischer Herrscher an griechische Städte und Heiligtümer. Berlin: Akademie Verlag.

Brodd, J. and Reed, J.L. (eds.) (2011). Rome and Religion. A Cross-Disciplinary Dialogue on the Imperial Cult. Atlanta: Society of Biblical Literature.

Bru, H. and Demirer, Ü. (2007). Dionysisme, culte impériale et vie civique à Antioche de Pisidie. Revue des Études Anciennes, 109.1, pp. 27-49.

Bru, H. (2016). Le cult imperial dans l'Orient romain: mythes, rites et structures. In Kolb and Vitale, 2016, pp. 57-77.

Burkert, W. (1985). Greek Religion. Cambridge, Mass.: Harvard University Press.

Byrne, S.G. (2003): Roman Citizens of Athens. Leuven and Dudley, Ma.: Peeters.

Cabanes, P. (1987). L'Empereur Hadrien à Nicopolis. In Chrysos, 1987, pp. 153-167.

Camia, F. (2011a). Theoi Sebastoi. Il culto degli imperatori romani in Grecia (Provincia Achaia) nel secondo secolo d.C. Meletemata LXV. Atene: Ethnikon Hidryma Ereunōn.

Camia, F. (2011b). Lykos, son of Hermolaos, hiereus heptaeterikos of the Sebastoi. Emperor Worship and Traditional Cults at Thessalian Hypata (SEG 54, 556). Zeitschrift für Papyrologie und Epigraphik, 179, pp. 145-154.

Camia, F. (2017). La titolatura dei sacerdoti del culto imperiale in Grecia: terminologia ed evoluzione. Historika, 7, pp. 451-489. 
Cancik, H. and Hitzl, K. (eds.) (2003). Die Praxis der Herrscherverehrung in Rom und seinen Provinzen, Akten der Tagung in Blaubeuren vom 4. bis zum 6. April 2002. Tübingen: Mohr Siebeck.

Cartledge, P. and Spawforth, A.J.S. (2002). Hellenistic and Roman Sparta. A tale of two cities. London and New York: Routledge.

Chaniotis, A. (2003a). Der Kaiserkult im Osten des Römischen Reiches im Kontext der zeitgenössischen Ritualpraxis. In Cancik and Hitzl, 2003, pp. 3-28.

Chaniotis, A. (2003b). The Divinity of Hellenistic Rulers. In Erskine, 2003, pp. 431-445.

Chaniotis, A. (ed.) (2011). Ritual Dynamics in the Ancient Mediterranean. Agency, Emotion, Gender, Representation, Stuttgart: F. Steiner.

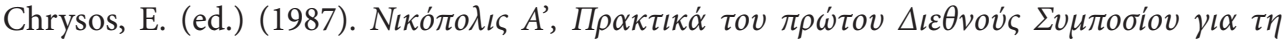

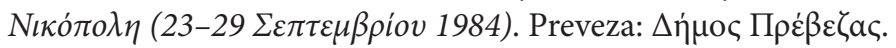

Clauss, M. (1999). Kaiser und Gott. Herrscherkult im römischen Reich. München and Leipzig: Teubner.

Cortés Copete, J.M. (2017). Hadrian Among the Gods. In Muñiz Grijalvo, Cortés Copete and Lozano Gómez, 2017, pp. 112-136.

Deshours, N. (2004). Cultes de Déméter, d'Arémis Ortheia et culte impérial à Messène (1 $1^{\text {er }}$ s. av. notre ère $-1^{\mathrm{er}}$ s. de notre ère). Zeitschrift für Papyrologie und Epigraphik, 146, pp. 115-127.

Dowden, K. (2007). Olympian gods, Olympian Pantheon. In Ogden, 2007, pp. 41-55.

Dunand, Fr. (1973). Le culte d'Isis dans le bassin oriental de la Méditerranée, 3 vols. Leiden: Brill.

Dunand, Fr. (1986). Les associations dionysiaques au service du pouvoir lagide (IIIe s. av. J.-C.). In L'association dionysiaque dans les sociétés anciennes. Actes de la table ronde organise parl'École française de Rome (Rome 24-25 mai 1984) (pp. 85-103). Rome: École Française de Rome.

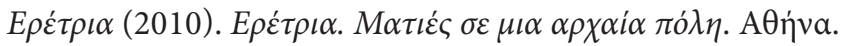

Erskine, A. (ed.) (2003). A Companion to the Hellenistic World. Oxford: Wiley-Blackwell.

Étienne, R. (2004). Athènes. Espaces urbains et histoire. Des origines à la fin du III siècle ap. J.-C. Paris: Hachette.

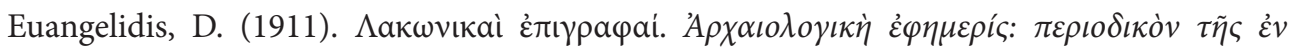

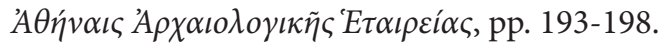

Fishwick, D. (1987-2004). The Imperial Cult in the Latin West. Studies in the Ruler Cult of the Western Provinces of the Roman Empire, I-III. Leiden: Brill.

Follet, S. (1976). Athènes au II et au III siècle. Études chronologiques et prosopographiques. Paris: Les Belles Lettres.

Freitag, K., Funke, P. and Haake, M. (eds.) (2006). Kult - Politik - Ethnos. Überregionale Heiligtümer im Spannungsfeld von Kult und Politik (Kolloquium, Münster, 23-24 November 2001). Stuttgart: Franz Steiner Verlag.

Frija, G. (2012). Les Prêtres des empereurs: le culte impérial civique dans la province romaine d'Asie. Rennes: Presses Universitaires de Rennes. 
Fujii, T. (2013). Imperial cult and imperial representation in Roman Cyprus. Stuttgart: Franz Steiner Verlag.

Galli, M. and Tozzi, G. (2016). Le prime manifestazioni del culto del princeps nell'Oriente greco: il caso di Kalindoia. In Baglioni, 2016, pp. 239-259.

Geagan, D.J. (1972). Hadrian and the Athenian Dionysiac Technitai. Transactions of the American Philological Association, 103, pp. 133-160.

Goyette, M. (2010). Ptolemy II Philadelphus and the Dionysiac Model of Political Authority. Journal of Ancient Egyptian Interconnections, 2.1, pp. 1-13.

Gradel, I. (2002). Emperor Worship and Roman Religion. Oxford: Clarendon Press.

Graf, F. (2011). Ritual restoration and innovation in the Greek cities of the Roman Empire. In Chaniotis, 2011, pp. 105-118.

Graindor, P. (1934). Athènes sous Hadrien. Le Caire: Imprimerie Nationale.

Habicht, Chr. $\left(1970^{2}\right)$. Gottmenschentum und griechische Städte. München: Beck.

Hahn, U. (1994). Die Frauen des römischen Kaiserhauses und ihre Ehrungen im griechischen Osten anhand epigraphischer und numismatischer Zeugnisse von Livia bis Sabina. Saarbrücken: Saarbrücker Druckerei und Verlag.

Halfmann, H. (1986). Itinera principum. Stuttgart: Franz Steiner Verlag.

Hänlein-Schäfer, H. (1985). Veneratio Augusti. Eine Studie zu den Tempeln des ersten römischen Kaisers. Roma: G. Bretschneider.

Herz, P. (1993). Die Adoptivsohne des Augustus und der Festkalender. Gedanken zu einer Inschrift aus Messene. Klio, 75, pp. 272-288.

Hitzl, K. (1991). Die kaiserzeitliche Statuenausstattung des Metroon, OF 19. Berlin: De Gruyter. Hoepfner, W. (ed.) (1997). Das dorische Thera V. Stadtgeschichte und Kultstatten am nördlichen Stadtrand. Berlin: Gebr. Mann.

Hoët-Van Cauwenberghe, Chr. (1999). Notes sur le culte impérial dans le Péloponnèse. Zeitschrift für Papyrologie und Epigraphik, 125, pp. 177-181.

Hupfloher, A. (2000). Kulte im kaiserzeitlichen Sparta. Eine Rekonstruktion anhand der Priesterämter. Berlin: Akademie Verlag.

Hupfloher, A. (2006). Kaiserkult in einem überregionalen Heiligtum: das Beispiel Olympia. In Freitag, Funke and Haake, 2006, pp. 239-263.

Iossif, P.P., Chankowski, A.S. and Lorber, C.C. (eds.) (2011). More than men, less than gods: Studies on royal cult and imperial worship. Proceedings of the international colloquium organized by the Belgian school at Athens (November 1-2, 2007). Studia Hellenistica LI. Leuven: Peeters.

Jacopi, G. (1932). Nuove epigrafi dalle Sporadi meridionali. Clara Rhodos, 2, pp. 165-256.

Kajava, M. (2001). Vesta and Athens. In Salomies, 2001, pp. 71-94.

Kantirea, M. (2007). Les dieux et les dieux Augustes. Le culte impérial en Grèce sous les Julioclaudiens et les Flaviens. Etudes épigraphiques et archéologiques. Meletemata L. Athènes: Ethnikon Hidryma Ereunōn. 


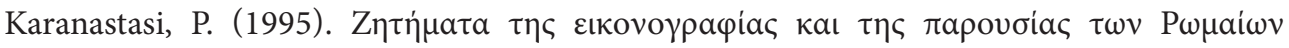

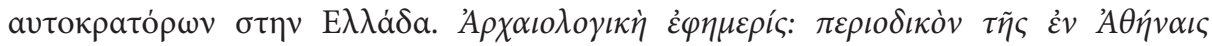

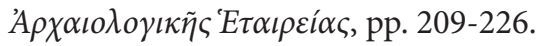

Kearsley, R.A. (2005). Women and Public Life in Imperial Asia Minor: Hellenistic Tradition and Augustan Ideology. Ancient West and East, 4, pp. 98-121.

Kolb, A. and Vitale, M. (eds.) (2016). Kaiserkult in den Provinzen des romischen Reiches. Organisation, Kommunikation und representation. Berlin and Boston: Walter de Gruyter \& Co.

Koonce, K. (1988). АГА МMA and EIK $\Omega$ N. American Journal of Philology, 109, pp. 108-110.

Kraeling, C.H. (1962). Ptolemais. City of the Libyan Pentapolis. Chicago: University of Chicago Press.

Lozano Gomez, F. (2010). Un dios entre los hombres. La adoración a los emperadores romanos en Grecia. Barcelona: Universidad de Barcelona.

Ma, J. (2013). Statues and cities: honorific portraits and civic identity in the Hellenistic world, Oxford: Oxford University Press.

Maas, M. (1972). Die Prohedrie des Dionysostheaters in Athen. München: Beck.

Maiuri, A. (1925). Nuova silloge epigrafica di Rodi e Cos. Firenze: Le Monnier.

Manieri, A. (2009). Agoni poetico-musicali nella Grecia antica. 1. Beozia. Pisa and Roma: F. Serra.

Muller, A. (1981). Megarika. Bulletin de Correspondance Hellénique, 105, pp. 203-225.

Muñiz Grijalvo, E., Cortés Copete, J.M. and Lozano Gómez, F. (eds.) (2017). Empire and Religion. Religious Change in Greek Cities under Roman Rule. Leiden: Brill.

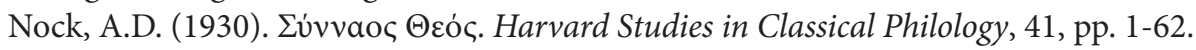

Ogden, D. (ed.) (2007), A Companion to Greek Religion, Oxford.

Ohlemutz, E. (1940). Die Kulte und Heiligtümer der Götter in Pergamon. Wurzburg: Wissenschaftliche Buchgesellschaft.

Oliver, J.H. (1940). Julia Domna as Athena Polias. Athenian Studies presented to William Scott Ferguson. Harvard Studies in Classical Philology Suppl. I (pp. 521-530). Cambridge, Ma.: Harvard University Press.

Oliver, J.H. (1970). Marcus Aurelius. Aspects of Civic and Cultural Policy in the East. Hesperia Suppl. XIII. Princeton: ASCSA.

Pleket, H.W. (1965). An Aspect of the Emperor Cult. Imperial mysteries. Harvard Theological Review, 58, pp. 331-347.

Price, S.R.F. (1984). Rituals and Power. The Roman Imperial Cult in Asia Minor. Cambridge: Cambridge University Press.

Prignitz, S. (2011). Ein Augustuspriester der Jahres 27 v. Chr. Zeitschrift für Papyrologie und Epigraphik, 178, pp. 210-214.

Richards, Fr. (1988). Les souverains en «Theoi epibaterioi». Cahiers d'Histoire, 33, pp. 441452.

Rizakis, A.D. (1995). Achaïe I. Sources textuelles et histoire régionale. Meletemata XX. Athènes : Ethnikon Hidryma Ereunōn. 
Rizakis, A.D. (1998). Achaïe II. La cité de Patras: épigraphie et histoire. Meletemata XXV. Athènes: Ethnikon Hidryma Ereunōn.

Rizakis, A.D. (2009). La colonie de Patras en Achaïe dans le cadre de la colonisation augustéenne. In Patrasso colonia di Augusto e le trasformazioni culturali, politiche ed economiche della Provincia di Acaia agli inizi dell'età imperiale romana. Atti del Convegno internazionale, Patrasso 23-24 marzo 2006 (pp. 17-38). Atene: Scuola archeologica italiana di Atene.

Rizakis, A.D., Zoumbaki, S. and Lepenioti, Cl. (2004). Roman Peloponnese II. Roman personal names in their social context. Meletemata XXXVI. Athens: Ethnikon Hidryma Ereunōn.

Robert, L. (1940). Les gladiateurs dans l'Orient grec. Paris: E. Champion.

Robert, L. (1966). Sur un decret d' Ilion et sur un papyrus concernant des cultes royaux. American Studies of Papyrology, 1, pp. 175-211.

Roux, G. (1965). Pausanias, le "Contre Aristogiton” et les “énigmes de Marmaria” à Delphes. Revue des Études Anciennes, 67, pp. 48-53.

Rutherford, I. (2010). Canonizing the Pantheon: the Dodekatheon in Greek Religion and its Origins. In Bremmer, and Erskine, 2010, pp. 43-54.

Salomies, O. (ed.) (2001). The Greek East in the Roman Context. Proceedings of a Colloquium organised by the Finish Institute at Athens May 21 and 22, 1999. Papers and Monographs of the Finish Institute at Athens VII. Athens: Bookstore Tiedekirja.

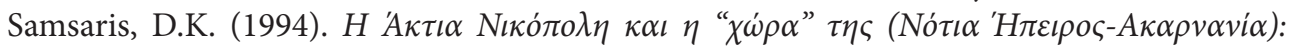

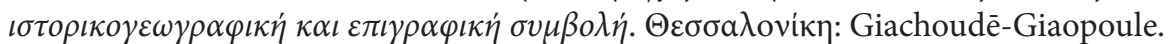

Schachter, A. (1981-1994). Cults of Boiotia. 1. Acheloos to Hera. 2. Herakles to Poseidon. 3. Potnia to Zeus. 4. Index of Inscriptions. Bulletin of the Institute of Classical Studies Suppl. XXXVIII.1-4. London: Institute of Classical Studies.

Schmalz, G.C.R. (2009). Augustan and Julio-Claudian Athens. A New Epigraphy and Prosopography. Leiden and Boston: Brill.

Schmid, S.G. (2001). Worshipping the emperor(s): a new temple of the imperial cult at Eretria and the ancient destruction of its statues. Journal of Roman Archaeology, 14, pp. 113142.

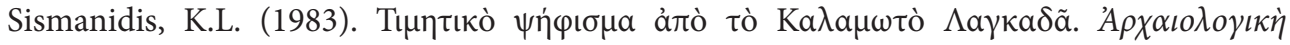

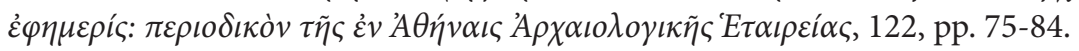

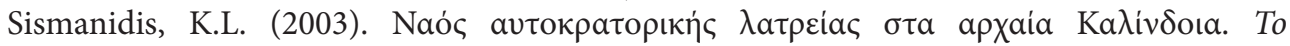

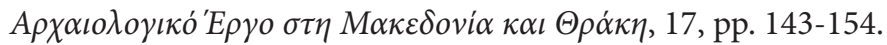

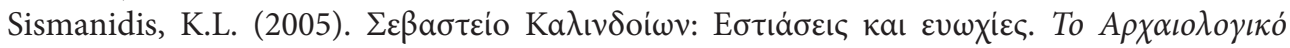

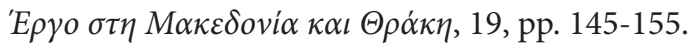

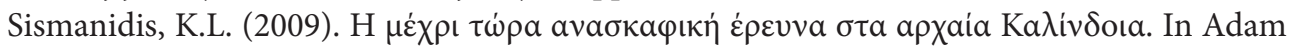
Veleni and Tzanavari, 2009, pp. 317-328.

Takàcs, S.A. (1995). Isis and Sarapis in the Roman World. Leiden: Brill.

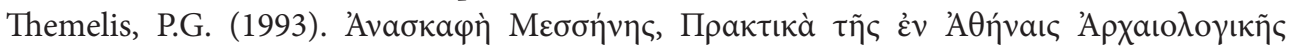
'Eтaıpéas, 148, pp. 48-72.

Theodoridis, C. (1998). Photii Patriarchae Lexicon, II. Berlin and New York: De Gruyter. 
Thompson, H.A. (1966). The Annex to the Stoa of Zeus in the Athenian Agora. Hesperia, 35, pp. 171-187.

Travlos, J. (1971). Pictorial Dictionary of Ancient Athens. New York: Hacker Art Books.

Vermaseren, M.J. (1982). Corpus cultus Cybelae Attidisque. II. Graecia atque insulae. Leiden: Brill.

Veyne, P. (1962). Les honneurs posthumes de Flavia Domitilla et les dédicaces grecques et latines. Latomus, 21, pp. 49-98.

Vitale, M. (2016). 'Priest' - 'Eparchy-arch' - 'Speaker of the ethnos': Areas of Responsibility of Highest Officials of the Eastern Provincial Imperial Cult. Mnemosyne, 69, pp. 82-111.

Weber, W. (1907). Untersuchungen zur Geschichte des Kaisers Hadrianus. Leipzig: Teubner.

Witschel, C. (1997). Beobachtungen zur Stadtenwicklung von Thera in hellenistischer und römischer Zeit. In Hoepfner, 1997, pp. 17-46.

Wycherley, R.E. (1957). The Athenian Agora. Results of Excavations Conducted by the American School of Classical Studies at Athens. Volume III. Literary and Epigraphical Testimonia. Princeton: ASCSA.

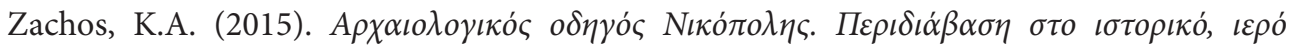

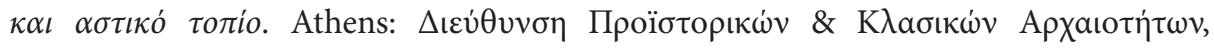

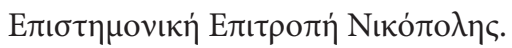

